\title{
The Trilemma and the Eurozone: A Pre-announced Tragedy of the Hellenic Debt Crisis
}

\author{
Eleftherios Thalassinos* and Theodore V. Stamatopoulos**
}

\begin{abstract}
:
The main aim of this article is to analyse the theoretical background regarding monetary policy, money and capital markets with a reference to the Greek economy.

From an international point of view the recent crisis has been affected by the incompleted financial market, problems of instability and political failure. The structure of Eurozone was another weak link in the establishment of an effective economic environment able to survive during the recent financial crisis however most of the concequences have affected the weak economies of the region. In fact the Hellenic economy with the structural inequilities in the labor, money and capital markets has been influenced hardly because the Greek government failed to take measures to manage the crisis.
\end{abstract}

The Internationaal Financial Non-System with the trilemma problem in the design of a strong monetary policy can be attributed to the Hellenic crisis in a specific way as it is described in the article.

Key words: Trilemma, financial crisis, debt crisis.

*University of Piraeus, Karaoli and Dimitriou 80, 18533 Piraeus, Thalassinos@ersj.eu

**TEI of Crete, Estavromenos, Heraclion Crete 


\section{Introduction}

The present paper focuses on the political and economic reasons that lead to the Greek debt crisis in 2009 as well as the economic consequences for the Hellenic society and other member countries of the Eurozone. In general, the protected Hellenic economy, the lack of external disequilibrium and all kinds of debt issues evolved until the early 80s, all well-known to Greek governments long before 2009 from official reports, along with the strong economic transformation from a "coordinated market economy" or "South European capitalism" to a "liberal market economy" in the period following lead to the debt crisis of 2009. European authorities in the name of Europe as an economic and monetary union imposed the "liberal market economy", as yet incomplete. Hellenic politicians nevertheless have their share of responsibility.

From an international economic point of view, the Hellenic debt crisis is found to be connected with, first, the institutional framework of the "de-regulation" of money and capital markets ending up to the crash of 2008 and the ensuing systemiceconomic crisis in particular in the incomplete Eurozone and, second, the Trilemma monetary policy or Mundell's impossible trinity. More specifically, we distinguish between internal and external causes. Internal causes relate to bad domestic governance in the form of a lack of strategic planning for national economic development resulting in the severe pathology of generating a metapratic economy, gradually transformed from primary (agriculture, animal husbandry, fishing industry and mineral wealth) and much less secondary to mainly tertiary sector. As major external cause, we consider the lack of surplus recycling mechanism both internationally and within the non-optimal Eurozone.

More specifically, in order to explain why a member country like Greece could not react against the "markets" we take into consideration the International Financial Non-System (IFnS), including the collapse of the Bretton Woods, the collapse of the "Global Minotaur" Varoufakis (2011), as well as the recent historically confirmed Trilemma. Our findings, policy lessons suggesting mechanisms to prevent the Hellenic debt crisis, indicate the responsibilities of the policy makers, although not sufficient for the non-recurrence of such crises (for small, open, integrated or to be integrated countries) as history shows. We question whether Hellenic economic events up to the Eurozone era comply with empirical verification of the Trilemma within the global and the EU framework lacking surplus recycling mechanism (Thalassinos et al., 2013a and 2013b, Thalassinos et al., 2012; Thalassinos et al., 2015). The latter is evaluated on the basis of the theory of optimum currency areas, known as OCA.

The main conclusion of our study is that the Hellenic debt crisis could have been forecast and thus prevented, suggesting that the Eurozone should change so as to become an OCA including fiscal federalism and European macro-governance promoting homogeneity, otherwise, its disintegration will emerge as a necessity. 
Finally, based on policy implications of our conclusion we comment on recent EU institutional decisions in response to the Eurocrisis and the Hellenic crisis in particular, among others the European Financial Stability Facility (EFSF - ESF as of 2013) and the loan contracts including conditionality clauses demanded by the troika (EU, EC and IMF), known as Memorandum I (May, 2010 and Memorandum II (March, 2012).

\section{Approach}

\subsection{The Methodology}

Our approach, limited to the period from post-Bretton Woods up to the Hellenic debt crisis of 2009 and adjusted to the regional (EU) and the international ("Global Minotaur") institutional framework adopted (IfnS), includes critical research into whether the Hellenic economy is consistent with the Trilemma economic policy or not. If the Trilemma adjusted fits the data, events complying with the qualitative nature of our research, then the Hellenic debt crisis of 2009 should have been forecast and prevented.

Our theory is based on two axes, first, given the lack of surplus recycling mechanism since the collapse of the Bretton Woods system in 1971, the institutional framework imposed on the small open Hellenic economy is crucial for the configuration of the Trilemma adopted by the authorities, because the IFnS and the incomplete EU define either the way "markets" function or how governments approach their goals, second, based on the international economics theory and focusing on "Mundell's Trilemma economic policy or incompatible trinity", we are able to highlight the limitations policy makers faced in their objectives and instruments prior to the 2009 debt crisis.

Thereby, in open macroeconomics, policy makers are confronted with three typically desirable objectives, which are, (1) exchange rate stability (ERS), (2) monetary policy independence (MPI) towards domestic goals and (3) free capital movement or financial integration (FI). Given only two out of the three may be mutually consistent, transforming the third to instrument, the Trilemma for policymakers pertains to "which objective they have to give up, given the international payments system they have chosen or have to choose?"

\subsection{Literature Review}

The Trilemma has been historically confirmed by Obstfeld, Shambaugh and Taylor (2005, 2008, 2009) and Aizenman, Chinn and Ito (2008, 2010). The formulation of our research hypothesis was based on their influential works.

2.1.1 Obstfeld, Shambaugh and Taylor $(2005,2008,2009)$ 
In their work, OST ask the basic Trilemma question, "Do the exchange rate (ER) and capital controls $(C C)$ regimes influence the extent to which local interest rates (Rit) diverge from the 'world or base country's' rate?" Monetary Policy Independence (MPI) of the Trilemma is taken by the authors to mean the ability to drive local interest rates away from the world rate or base country's rate. They conclude that "Exchange Rate Regimes (ERR) do affect Monetary Policy Activism (MPI), that is the extent to which a country follows the base, but capital controls (CC) of the Bretton Woods era, seemed to significantly slow or even stop those reactions." Their research focused on three periods, (1), Gold Standard era: 18701914, (2) Bretton Woods era: 1959-1970 and (3) Post-Bretton Woods era: $1973-$ 2000 and on three Exchange Rate Regimes (Pool, Pegs, Nonpegs) plus "pool with interactive term".

Their conclusions with regard to the eras researched are outlined as follows:

(1) Within-era, the greater the Exchange Rate Stability (ERS) the lower the Monetary Policy Independence (MPI), given the Financial Integration (FI) chosen.

(2) Across-era, the Trilemma trade-offs may be expressed and represented as follows:

(i) Pegs and Free Capital Movement or Financial Integration (FI) objectives require the government to accept Monetary Policy Dependence (MPD) on the base's country. This schema represents Eurozone (2002- ), a period when Pegs coincide with Euro $(€)$ and MP Dependence with the European Central Bank's (ECB) monetary policy.

(ii) Non-Pegs and Free Capital Movement objectives allow reasonable Monetary Policy Independence (relative MPI). This schema represents Eurozone's member countries during the 1990s, post-EU treaty (1992) up to the entrance of their currencies to the narrow bound of the Exchange Rate Mechanism II of the European Monetary System (1997 for the first set of the countries or 1998 for Greece).

(iii) Either Pegs are rarely pure hand-cuffed (irrevocably ERS) or Non-Pegs are never purely freely floating (FER), that is often follow the base interest rate. In this schema definitions of Pegs and non-Pegs are not verified as rigid, thus making the other two more convincing and suitable.

(3) Pooled-era, Exchange Rate Regimes (ERR) and Capital Controls (CC) clearly affect interest rate autonomy (MPI):

(i) Floating Exchange Rates (FER) with Capital Controls (CC) seem to provide free monetary policy independence or autonomy (free MPI). This schema represents many countries after the collapse of the Bretton Woods.

(ii) Non-Pegs with open markets (FI) and Pegs with closed Capital Controls (CC) retain some interest rate autonomy (relative MPI). This schema might represent Hellas if we accept the validity of (5)(iii) above in terms of Pegs 
representing the Greek Drachmae (GRD) and capital controls in place until May 1194.

(iii) Pegs with open markets (FI) have the least monetary policy autonomy (the least MPI). This schema may be seen as another version of (5)(i) above in the pooled-era.

2.1.2 Aizenman, Chinn and Ito $(2008,2010)$

In their research, they came up with the following conclusions:

(i) Trilemma policy goals are "binding" in the context of the impossible trinity. Any change in one of the Trilemma variables (ERS, MPI, FI) shall induce a change with the opposite sign in the weighted average of the other two. However, countries alter over time the weights of the Trilemma objectives.

(ii) Structural breaks in the Trilemma indices have been proven to be associated with major economic events in the international financial nonsystem (IFnS).

(iii) Policy choices on Trilemma configuration surely affect macroeconomic performance of the countries.

(iv) Trilemma configurations and domestic financial development or net external finance affect macroeconomic performance.

(v) Trilemma configurations either affect more differently macroeconomic performance of "crisis economies' than of tranquil ones or are changed after a "crisis".

\subsection{Institutional framework}

\subsubsection{European Union and Hellas: Links of Political Economy}

European Leaders undoubtedly promote the "economic" unification rather than any "political" unification or "sympolity", as it has been suggested, accompanied by a "Constitutional Treaty" (Tsatsos, 2001). Over the years, though, Federalists and Eurosceptics unconsciously work for breaking down the Euro zone.

2.3.2 European Economic and Monetary Union: Centrifugal Forces from SteadyState Economic Equilibrium

The European Economic and Monetary Union (EMU henceforth) has been created under the Maastricht Treaty (1992) as a sui generis middle type of international economic integration, that is, between two theoretical types of "economic union" and "total economic union". In this sense, the EU Treaty established the European System of Central Banks (European Central Bank - ECB) as a supranational authority for running monetary policy for the common currency, the Euro. ECB, unlike any other central bank in the world, operates above and beyond the reach of 
any single national government under the mandate to pursue price stability, while the European Parliament has little power with regard to altering its statute. Furthermore, with regard to the incomplete fiscal policy harmonization in the EMU, governments of EMU-members are under rigid constraints in the exercise of their national fiscal powers, even in emergency states of sudden national recessions.

The underlying economic theory is the Optimum Currency Areas (OCA). Although there is evidence in favor of the enhancement of financial integration as a result of the Euro, Europe's product and factors markets have not sufficiently been unified yet. Given EMU is not yet optimal, as the respective OCA theory asks, it is well justified to assess economic policy choices and their consequences using the theoretical framework of Mundell's incompatible trinity. The founders of the EMU, following the currency crisis of 1992-1993, gave up monetary policy to ESCB and preserved the Financial Integration (FI) and the Exchange Rate Stability (ERS) through the adoption of the Euro, as the Trilemma predicts. Practically, issues related to price stability and real economy was allocated to the ECB and the national governments respectively. Within this framework of ERS plus FI and the straitjackets of (1) the procedure of excessive deficits (PED), (2) the stability and growth pact (SGP) and (3) the peculiar ECB's regulation without normal scope for central banks (e.g. "lender of last resort"), it is not to wonder about the rise of public debts in the Eurozone countries of 2000s, especially after the global crunch of 2008 and the ensuing depression.

In this regional framework, Hellas deprived itself of the luxury of exchange rate policy till 1998 as soon as it became a member of the EMU. Thus, as a small open economy characterized as badly governed, in the sense of not having made the necessary structural reforms within the Eurozone so as to restore its competitiveness, transformed the lenders' willingness to invest into panic that lead to a liquidity crisis in the Hellenic banking sector. Furthermore, being an EMU member, its temporary liquidity problem could easily convert into a crisis, banking or sovereign given the Eurozone system lacks a mechanism of automatic stabilizer for equilibrating money and/or capital local markets.

To the contrary, if outgoing euro-funds get out of Greek government bonds running to another EMU country-member as a safety shelter, then rising yields in Hellenic securities (forcing the country to bankrupt, if for instance markets "believe" that the sovereign debt is unsustainable), probably result in reduced yields of the safety shelter country-member. At the same time, increasing spreads may be the cause, through intensifying the Hellenic outflows, of a higher cost of Hellenic borrowing or lower cost to the safety shelter partners, or even more likely to both of them. The ECB managed to mitigate the deleveraging Hellenic pain only within the unofficial "quantitative easing" practice after 2008 global crunch by way of accepting Hellenic government bonds from banks as collateral to lend them Euro in order to prevent the banking crisis. This represents the obvious lack of chain links in the EMU system. Fiscal Federalism, as a first step towards fiscal union, could be an answer within the 
framework of structural reforms in European integration architecture, aiming at total economic integration type, in the sense predicted by the OCA theory.

Given the lack of control over the currency (Euro) an EMU-member's debt has been issued, there is no way out, but bankruptcy for those that have been awarded the label of "insolvent" by markets. Hellas in particular has been obliged under two austerity plans to follow an internal devaluation hoping to reserve flows, thus leading the country's debt transformation to foreign exchange and its downgrade. It will be no surprise if the economic crisis along with the social crisis and the austerity plans combined lead to a humanitarian crisis after all.

2.3.3 International Financial Non-System in the post-Bretton Woods era: Global Minotaur and Bankruptocracy

The allegory of the Global Minotaur characterizes the mechanism of surplus recycling developed in the post-Bretton Woods era: starting from the 1960's, US merchandise trade changed into deficit along with the budgetary deficit. Upon the collapse of the Bretton-Woods system, US policy makers arranged for European, Asian and oil exporters' surpluses, made mainly in the US output market, to return by almost $80 \%$ to Wall Street or US bonds, financing this way US twin deficits. At the same time, they also managed to restore US citizens' purchasing power for foreign goods and services and thus retain their economic hegemony.

The main factors, from a geopolitics point of view, that allowed the Global Minotaur to "attract" its food are the following:

(i) The "exorbitant privilege" or the role of the USD as a global reserve currency that attracted incoming funds to Wall Street or FED bonds, thus boosting dollar exchange rates.

(ii) The growing cost of energy that lead OPEC profits and European and Asian profits from innovations against the increase of energy cost to transfer them to Wall Street or FED bonds.

(iii) The cheap and productive labor in the US compared to that of Europe and Asia. More specifically, the US managed to steadily decrease wages while at the same time doubling labor productivity, attracting foreign funds and firms to New York stock exchange.

(iv) The geo-political power of the US undoubtedly played a great role in supporting the credibility of US dollar and capital markets.

Other economic and political factors that permitted the growth of the Global Minotaur are the following:

(i) Mergers and Acquisitions. More specifically, enormous flows from the rest of the world united with domestic corporate profits provoked a wave of mergers and acquisitions, thus financing the US twin deficits.

(ii) The ideology of cheap in the age of excess: the Wal Mart phenomenon. The latter responded to decreasing purchasing power of lower incomes of Americans with reducing prices of its output. Wal Mart contributed to 
reducing inflation, which in turn was necessary in order to maintain the Global Minotaur.

(iii) Wall Street private-toxic money. Collateralized debt obligations (CDOs) or securitized derivatives (SDs, eg. Credit Default Swaps - CDS) have been proven to be the smartest securities golden boys and girls constructed and sold in the derivatives market (Thalassinos 2014; Thalassinos et al., 2014). These sophisticated forms of indebtedness are considered "private" in the sense that they escape monetary authorities' control and "toxic" in the sense that they distorted markets equilibrium.

(iv) Toxic economic theories and supply-side economics. It has also been proven that neither theory of efficient market hypothesis can combine time and complexity at the same time, thus they cannot predict a crisis which by nature is a dynamic phenomenon. The deregulation caused by the President Clinton administration (i.e. the abolishment of the Glass-Steagall Act in 1999) enabled commercial banks to invest depositors' savings in risky Wall Street securities, creating that way private-toxic money that "burned" in the late 2000 's, bringing to Hellas, amongst others, the ensuing economic crisis.

Under these circumstances, excess supply in labor and financial markets is not settled by the decrease in prices, because firms are afraid that the current decline in wages reflects future reduced demand for their products. To that end, they decrease their demand on labor and bank loans even more. In cases of firms relying on bank loans, bankruptcy seems possible. Recession deepens as pro-cyclical is preferred over counter-cyclical policy implementation attributed to fear that comes from the lack of solvency for CDOs and goes on for banks that have mountains of these derivatives in their investment portfolio. Banks either cannot or are afraid of lending to businesses, thus transferring the liquidity problem of insolvent banks to healthy banks and the real economy after all.

The "Global Minotaur" survived until 2009. Then it was "Bankruptocracy" that took over. More specifically, bail out of a crucial part of the private sector, for plausible general equilibrium economic reasons, would be made at the expense of taxpayers, who pay the rise in government debt. The more official sector's bonds are sold in the capital markets, so as to finance failed management of banks, the more costly is the sovereign debt and the more austerity is imposed on citizens in order to save the necessary funds. The irony is that states borrow from "capital markets" (banks or financial institutions broadly speaking) at high interest rates, mainly because markets evaluate only the borrower and not its intention to rescue the general economic activity.

After the 2008 global crunch, banks that bought government bonds also bought CDS for hedging purposes against respective bankruptcy risk. The more increase in a CDS' price, the more increase in the respective yield of the bond and rise ultimately of spreads (yield's difference between domestic and base countries' bonds). The CDS market operations created a new era of private-toxic money just as the CDOs 
did in the past. They both share one thing in common: the properties of money. "Zombie banks" are responsible for both banking and sovereign crises. As a crisis originated in a country can easily spread around the world through trade and factors' movements, it is no surprise that as of 2008 we have been experiencing a global systemic crisis in progress. The public sector intervention for regulation purposes, in both international and regional level, is indispensable.

Following the above, our research hypothesis is formatted as follows: The Hellenic government debt crisis of 2009 can be explained, given the bad domestic governance, either by the collapse of the international financial non-system in the crash of 2008, as well as, by the regional non-optimal EMU system, or by the historically confirmed Mundell's Trilemma economic policies.

\section{Findings and Discussion: combination of Trilemma and Institutional Framework in the Hellenic case 1971-2009}

By combining the historically confirmed Trilemma economic policy with the institutional framework of surplus recycling mechanism (either the Eurozone in regional level or the Global Minotaur and later the Bankruptocracy in international level) we evaluated our research hypothesis. In our evaluation we distinguish postBretton Woods era in the following sub-periods for the analysis of the Hellenic case using the Trilemma policy orientation as a criterion:

First Sub-Period: 1971-1981

The Trilemma configuration chosen by the Hellenic authorities is the following:

(i) Exchange Rate Stability (ERS): crawling peg of the drachmae (GRD) or de facto peg with basket currencies in which the USD has the crucial role (quasiUSD peg). Thus, relative ERS is valid.

(ii) Monetary Policy Independence (MPI): for a small relative closed economy it is plausible to accept high MPI.

(iii) Financial Integration (FI): the Bank of Greece (BoG) still uses capital controls (CC) continuing the Bretton Woods prediction.

Hellas' policy orientation may be described as "financially closed economy regime (FCER)". Although the country has ratified an association agreement with the European Economic Community (EEC) since 1961, it is not a member yet. There are no significant international commitments in this era, nor is there external equilibrium while the government debt is not worth mentioning.

Literature evidence on the effects of this Trilemma configuration is consistent with actual Hellenic economic performance at that time. More specifically, Hellenic FCER has been associated with lower domestic output volatility.

Second Sub-Period: 1981-1994 
Given that Hellas is now a full member of the European Economic Community (EEC), the Trilemma configuration chosen by the Hellenic authorities is the following:

(i) Exchange Rate Stability (ERS): De facto crawling-peg of GRD with basket currencies in which the DEM has the crucial role (quasi-DEM peg). The growth rate of crawling is reduced after 1987 so as to not cover the inflation differential; efforts from the BoG for rising real competitiveness of the "infant" Hellenic industry. The commitments to European Monetary System (EMS) as a zone of relative ERS are the determinant of the relative policy. Thus, relative ERS is valid.

(ii) Monetary Policy Independence (MPI): BoG still has relative MPI even less EMS than in the previous sub-period, given relative ERS and CC.

(iii) Financial Integration (FI): the country still uses capital controls (CC) while based on EMS has been committed to open financial markets later than min-1990 as it was the case for the majority of EEC members. That was done in 1994.

In Trilemma terms, during this period Hellas enjoys fewer "degrees of freedom" towards full ERS. Its policy orientation may be described as quasi-financially closed economy regime (quasi-FCER). As a full member of the EEC since 1981, the country has certain regional commitments. In the early 1980's for the first time in a long time deficit appears in the balance of current accounts, while government debt started to grow, though still at low level as a ratio of the GDP. BoG issues the government debt in GRD under the Hellenic laws and controls the currency (GRD) of the debt.

Literature evidence on the effects of this Trilemma configuration on macroeconomic performance is consistent with actual Hellenic economic performance at that time. Amongst others, it is valid that Hellenic even quasi-FCER has been associated with lower domestic output volatility.

Third Sub-Period: 1994-2001

The Trilemma configuration chosen by the Hellenic authorities is the following:

(i) Exchange Rate Stability (ERS): De facto hard crawling-peg of GRD with basket currencies in which the DEM has the crucial role (quasi-DEM hard peg). The country implements the "convergence program" so as to fulfill the Maastricht criteria for entrance to the EMU. In February 1998 it enters the narrow band of ERM-II. Thus, ERS is almost valid.

(ii) Monetary Policy Independence (MPI): BoG has very little MPI now, given almost ERS and free capital movement regime adopted from the beginning of the period.

(iii) Financial Integration (FI): the free capital movement regime adopted from the beginning of the period. 
In Trilemma terms, Hellas' policy orientation may be described as quasi-monetary union or currency board (quasi-MU-CB). There are growing significant regional commitments (EU treaty, course towards EMU). The average debt during this period reached approximately $100 \%$ as ratio to the GDP, higher than the required Maastricht criteria, but in downward trend since 2002. BoG still issues the government debt in GRD, under the Hellenic laws, and relatively controls the currency (GRD) of the debt.

Literature evidence on the effects of this Trilemma configuration on macroeconomic performance is consistent with actual Hellenic economic performance at that time. Amongst others, it is valid that quasi-MU-CB has been associated with higher inflation volatility and lower level of inflation.

Fourth Sub-Period: 2001-2008

The Trilemma configuration chosen by the Hellenic authorities is the following:

(i) Exchange Rate Stability (ERS): with euro (€) as its national currency, ERS in the intra-EMU transactions is valid.

(ii) Monetary Policy Independence (MPI): monetary policy is allocated to the ESCB-ECB.

(iii) Financial Integration (FI): the free capital movement regime has already been adopted since 1994, the beginning of the previous sub-period.

In Trilemma terms, the Hellenic economic policy configuration is the "monetary union (MU)". There are strong regional commitments (EMU, SGP) considered with relatively lax attention by domestic authorities. In the late 1990s the debt was around $100 \%$ as ratio to the GDP, higher than the required Maastricht criteria, but in downward trend (since 2002). BoG still issues the government debt in national currency, under the Hellenic laws, but the great difference is that it lost the opportunity to control the currency of the debt. Thus, the combination of the dynamics of expenditures for the Olympic Games in 2004 and excessive liquidity offered country's during the integration into the EMU caused asymmetric excess domestic demand as opposed to its European major partners (first half of 2000s). ECB could not naturally support the small Hellenic economy, with its debt minimum in $2003(97,4 \%$ as ratio of the GDP, lower even than that in 1994) and after 2005 (peak) to follow a short period of downward trend till the 2008 crunch. However, policy makers did not consider the chronic competitiveness problems of the economy in times of euphoria of financial markets.

The irony is that in the same period, wise leading economists suggested that the current account (CA) deficits would probably lead to dangerous accumulation in the government debt. According to them, Hellas should worry about its CA deficits and try to reduce it. EMU and its policy makers did not pay any attention to the 
inconsistency in EMU's original design and the need for regulation in financial markets.

Literature evidence on the effects of this Trilemma configuration on macroeconomic performance is consistent with actual `Hellenic performance. Amongst others, it is valid that Hellenic performance ever since the country became a member of the EMU has been associated with higher output and inflation volatility.

Fifth Sub-Period: 2008-

The Trilemma configuration chosen by the Hellenic authorities is the same with that of the previous sub-period.

As of 2008, the year the Global Minotaur collapsed, nothing has been the same in the rest of the world. For a small EMU-integrated country with almost no economic policy instruments to react to the global recession, like Hellas, this is even harsher. Domestic banking sector had not been exposed to CDOs or CDS, it was both local and regional integration that caused the enlarged debt crisis of 2009; domestic factors may be limited to "bad governance", either in the sense that that politicians did not efficiently face chronic structural problems of the economy, or did not ahead of time ask for the implementation of EU Treaties, so as to prevent expansion of the crisis. Regional integration causes may refer to incomplete and non-optimal EMU.

In May 2010 and in October 2011, Europeans leaders decided the establishment of institutions bearing an essence of "punishment" instead of correction of the EMU imperfections and in general creation of conditions stated under the OCA theory. The European Financial Stability Facility (EFSF - ESM as of 2013 and on) and the Private Sector Involvement (PSI) mechanism, both associated with respective loan agreements ("memorandums", legitimated by respective Hellenic laws) conditioned on unprecedented clauses for a European country. Its partners treated Hellas as a company as regards either the bonds collateral, or, under UK or Luxembourg law, wherever the loans required. Legal issues are beyond the limits of our analysis, however insofar as institutions affect the operational context of the economy, we should note that there is no precedent to sovereign bonds to be issued in foreign law, as happened here with the loan agreements between Hellas and European partners. As far as the restructuring of the public sector is concerned, its repayment in total was the only efficient way to overcome the country's difficulties given the incomplete and non-optimal EMU and the lack of wisdom by local policy makers.

Thus, downward trend in debt of 2005-2007 period reversed in 2008 to an increasing growth rate. Both rising yields of "zombie banks" coming out of the country and plunging into recession caused by austerity programs imposed by the government Troika (EC, ECB, IMF) sharply increased the component "interest rate and GDP growth effects" of the debt's growth. The opposite is true for the "primary budget effect" which in 2008 from $87,3 \%$ in 2008 dropped to $11,3 \%$ of the total growth of the debt in 2011. The depression that followed after the implementation of the 
programs imposed by Troika proves that the latter failed in their fiscal consolidation goal.

Literature evidence on the effects of this Trilemma configuration on macroeconomic performance is consistent with actual Hellenic performance. Amongst others, it is valid that Hellenic performance after the 2008 crunch and the ongoing crisis of deep recession has been associated with higher output and inflation volatility.

We conclude by accepting our hypothesis, that is, inevitable debt crisis enforced by markets for Hellas suffering from bad domestic governance at the end of 2009.

\section{Concluding Remarks}

Our approach in the present paper leads to the conclusion that there was no way but the debt crisis for a small financially integrated economy in a currency union suffering from bad domestic governance like Hellas. Furthermore, Hellas was not the origin of the ongoing European crisis and thus should not be treated as such by European leaders. The programs implemented so far have lead to a humanitarian crisis that needs to be resolved at least through "emergency state" legislation, giving priority to the standard of living of people against creditors of the country. Hellas could repay its debt through a logical and sustainable way by implementing clauses of development and trade as Germany did in the post-World War II period. Nevertheless, the solution can only be political starting, as a "Modest Proposal", with the recognition that the Eurocrisis is threefold (a) investment crisis, (b) banking crisis and (c) sovereign crisis.

\section{References}

Aizenman, J., M. D. Chinn and H. Ito (2008), Assessing the Emerging Global Financial Architecture: Measuring the Trilemma's Configurations Overtime, NBER Working Paper No. 14533 http://www.nber.org/papers/w14533

Aizenman, J., M. D. Chinn and H. Ito (2010), The Financial Crisis, Rethinking of the Global Financial Architecture, and the Trilemma, ADBI Working Paper

213, http://www.adbi.org/files/2010.04.19.wp213.financial.crisis.gfa.trilemma.pdf

Mundell, R. A. (1961), A Theory of Optimum Currency Areas. American Economic Review, 51, 657-665.

Obstfeld, M., J. C. Shambaugh and A. M. Taylor (2005), The Trilemma in History: Tradeoffs among Exchange Rates, Monetary Policy, and Capital Mobility. The Review of Economics and Statistics, 87, No 3, (Aug. 2005), 423-438, The MIT Press, Stable URL: http://www.jstor.org/stable/40042939.

Obstfeld, M., J. C. Shambaugh and A. M. Taylor (2008), Financial Stability, the Trilemma, and International Reserves. NBER Working Paper No. 14217, Cambridge, MA: NBER, URL http://www.nber.org/papers/w14217.

Obstfeld, M., J. C. Shambaugh and A. M. Taylor (2009), Financial Instability, Reserves, and Central Bank Swap Lines in the Panic of 2008. NBER Working Paper No. 14826, Cambridge, MA: NBER, URL http://www.nber.org/papers/w1482

Thalassinos, I.E., Ugurlu, E., \& Muratoglu, Y. (2012). Income Inequality and Inflation in the EU. European Research Studies, 15(1), 127. 
Thalassinos, I.E, Liapis, K., Rovolis, A., Galanos, C. (2013a). The Clusters of Economic Similarities between EU Countries: A View Under Recent Financial and Debt Crisis. European Research Studies, 16(1), 41.

Thalassinos, I.E., Venediktova, B., Staneva-Petkova, D. (2013b). Way of Banking Development Abroad: Branches or Subsidiaries. International Journal of Economics and Business Administration, 1(3), 69-78.

Thalassinos, E.P. (2014). Credit Default Swaps and Sovereign Debt in Eurozone. Chapter book in Risk Management: Strategies for Economic Development and Challenges in the Financial System,(eds), D. Milos Sprcic, Nova Publishers, 255-278, ISBN: 978163321539-9; 978-163321496-5.

Thalassinos, I.E., Liapis, K. and Thalassinos, E.J. (2014). The role of the rating companies in the recent financial crisis in the Balkan and black sea area. Chapter book in

Economic Crisis in Europe and the Balkans, 79-115, Contributions to Economics, Springer International Publishing, DOI: 10.1007/978-3-319-00494-5-6.

Thalassinos, I.E., Th. Stamatopoulos, D.T. and Thalassinos, E.P. (2015). The European Sovereign Debt Crisis and the Role of Credit Swaps. Chapter book in The WSPC Handbook of Futures Markets (eds) W. T. Ziemba and A.G. Malliaris, in memory of Late Milton Miller (Nobel 1990) World Scientific Handbook in Financial Economic Series Vol. 5, Chapter 20.

Tsatsos, D. (2001), European Sympolity: for a Union of Peoples with Strong Homelands. Kastaniotis ed., (in Greek language), Athens, Hellas, http://www.kastaniotis.com/book/960-03-3131-6

Varoufakis, Y. (2011a), The Global Minotaur: America, the True Origins of the Financial Crisis and the Future of the World Economy - Economic Controversies. Zed Books, September 2011. 